\title{
SCHOLARSHIP IN PERSPECTIVE
}

\author{
ANDREW PHANG*
}

Although it is a trite fact that legal scholars ought to be concerned about the status and future of legal scholarship, it is rare to find an article that grapples with the problem in an honest and unambiguous fashion. This is why I found Professor Lasson's commentary on "Scholarship Amok: Excesses in the Pursuit of Truth and Tenure"1 most instructive and thought-provoking. The commentary touched, in fact, upon many personal concerns that have long troubled me about legal scholarship generally (indeed, it should be mentioned, many of the issues canvassed in the commentary can be generalised, with modifications of course, to apply to many other disciplines as well). These concerns, as well as the fact that the commentary has (to the best of my knowledge) received little comment, have prompted the present response. In deference to the general thrust and tenor of Professor Lasson's commentary, however, 1 have refrained from using many footnotes; I have in fact, ensured that the various arguments are as highly condensed as possible. It is also hoped that, if nothing else, this brief response would have achieved two broader objectives that it will be of at least some interest to readers of the Legal Education Review; and secondly, that Professor Lasson will be gratified by the fact that his views are being taken seriously by academics outside the United States of America.

There are many things to applaud in Professor Lasson's commentary - above all, his timely reminder that "law review scholarship" ought not to be the sole determinant of one's status in the academy. His honesty, albeit tinged with a sharp edge at times in the style of the late Professor Rodell, ${ }^{2}$ is, as already alluded to above, refreshing and his wry humour (witness for example, his 
"elaborate" graph at note 60 which is reminiscent of Robin Williams' putdown of "mechanistic poetry" in "Dead Poets Society") is more than welcome. What is disturbing, however, is his very sweeping and all too reductionist view of legal scholarship. He does not persuade me why his rather drastic observations (mostly negative) ought to prevail. The fact that law reviews will probably continue to thrive (as Lasson himself admits) does not, of course, swing the argument the other way either. I thus propose to briefly review the main thrust of his piece in order to demonstrate why it does not hold, in the final analysis.

Professor Lasson's arguments are quite clearly put. He is of the view that there is far too much law review writing (“... [f]or every pure scholar we have a dozen-and-a-half of the innocent ersatz, for every diamond a heap of rhinestones"); this enormous output of useless scholarship is geared in the main, toward "survival", viz, promotion and tenure. The result is a plethora of mediocre scholarship headed by esoteric titles, and aggravated by the many comprehensive periodical indexes that implicitly legitimatise such an intolerable situation. This then, is the picture painted. What of it? At first blush, it is persuasive. However, there are problems.

First, Lasson cites no real evidence to support his thesis. In fact, the sheer weight of numbers reflects, to a large extent, the nature of the discipline itself — at least in the common law world, where development, especially in case-law, is incremental and oftimes complex. Academic writings help to systematise this patchwork. Lasson may argue: even then, who so many? The fact of the matter is that academic discussion presupposes that as many sincerely held views on a particular topic as possible are desirable (even on potato-law, which may be of great practical importance in certain locations). And such encouragement in fact enhances the likelihood of really creative and novel ideas, not all of which may be off-thewall. In this regard - and as a slight digression - considerations of promotion and tenure are, admittedly, by no means irrelevant. But one should understand too, that motivations are never single, and one should not assume that all academics are fuelled primarily by such baser instincts. Furthermore, the written medium provides forums for impersonal discussion as well (computer data bases are plausible substitutes, but that is a matter of personal taste). Lasson also cites indiscriminately from a host of journals — probably for 
effect, but whilst it may raise a slight smile, deeper reflection will reveal that the (intentional?) juxtaposing of widely differing article titles does not really prove anything. The very concept of variety is a double-edged sword; variety can be useful simply because it allows for more focus and caters for different categories of audiences. And his reference to the geographical breadth of law reviews is unfair because in many (especially Third World) countries (and, I suspect, in the States as well), the law review constitutes the "academic motor" of the faculty concerned. And even if at the end of the day the articles are not all that enlightening, law reviews, in my view at least, provide the necessary encouragement and forums for the (especially) younger academics to develop and hone their writing skills (a point alluded to by Lasson himself) — in many ways, it is the process which is all-important.

Professor Lasson has even more specific views - inter alia, that such scholarship is irrelevant to practitioners and judges alike. I think that academics would be deluding themselves if they claim to be mainly practical. That is not the way the legal world operates, although it ought to. This does not mean, however, that all academic writing should consequently be confined to casebooks and "black letter law" treatises. Nor do we write solely for students and fellow academics. "Academic ideas” do not often influence or change deeply-held premises and values in society, but they occasionally do. Witness, for example, the very real effect American Realism had for many years. And, more specifically, many deeply-entrenched (but unjust) legal doctrines can only be changed at their conceptual core. One can, of course, cite examples from the other branches of the humanities as well. And even if all legal scholarship were destined to leave no impression whatsoever on the social landscape, what of it? For reasons that cannot be articulated, the world in general and the legal profession in particular, would be the worse off if we did not have writings on, for example, legal history and legal theory. And whilst legal scholarship cannot (unequivocally at least) claim the inherent virtues of, say, history, philosophy and literature, it can at least claim some affinity with something of the spirit behind the continued existence and flourishing of these disciplines.

Finally, Professor Lasson questions the very notion of 
scholarship itself in the context of the law reviews. His main argument is that scholarship is subjective in any event. His more specific grouses have to do with the horrid scourge of footnotes and the terrible style in which articles are written. He also bemoans (in the penultimate section of the commentary) the problems of academic ego. To deal with the last point first, it ought to be borne in mind that the line between professional pride and academic ego is often blurred. And whilst it is true that academics may have a tendency to be intellectually arrogant, arrogance per se is not their sole or even dominant preserve - and never will be. To return to the more specific points raised, it is my view at least that whilst it should not be the determinative criterion, academic writing provides a more than rough yardstick for the purposes of promotion and tenure. Lasson's chagrin vis-a-vis footnotes is understandable. But one ought not to underrate their uses - for example, to sift the relevant primary and secondary material; to give a succinct account of other important and related stories; to point the way toward important points of departure; and simply to educate those who desire to be educated on the finer points of a particular topic. The author's tirade with regard to style I found to be even less persuasive. There is always a tension between scholarship (which presupposes specialised terminology and concepts; of this, more later) on the one hand and communication on the other. And his selection of "difficult" passages of legal language is, in my view, patently unfair, simply because the choice was biased. Lasson chose philosophical pieces that had a vocabulary of their own; had he chosen passages taken from articles dealing with so-called "blackletter law", his point would almost certainly have had less impact.

To conclude, Professor Lasson's commentary is, on balance, far too extreme. It lacks evidential punch, and tends to gloss over the more basic premises underlying academic scholarship. It highlights all the bad points and downplays the good. It emphasises what is basically accepted as not constituting a major goal in at least most situations (viz, the sphere of practical influence), and underrates the intellectual training of both teacher and student alike. It takes the reductionist tack of equating all (or at least most) motivation for scholarship with economic considerations. And it would have us believe that the whole academy, which comprises intelligent 
individuals, is somehow involved in this mass conspiracy of sorts. What is most disturbing however (this is never explicit, although it comes close in comments on language and style), is the unstated premise that the law isn't so specialised after all. This however, raises much broader theoretical questions on the value and role of law in the larger social context - which raises, in turn, many subjective conceptions, all of which need to be advanced in public forums, inter alia, the law reviews. It is true that academics have problems of ego. It is also true that there are, by the sheer law of averages, the inevitable bad pieces. Professor Lasson's one-sided polemic, however, throws out the baby together with the bathwater. Above all, it discourages the aspiring academic who just might have something of worth to say. Even mature academics like Professor Lasson benefit from the present system, and his commentary is living proof of this. His views however, are his own subjective evaluations. So is this comment. But all need and ought to be heard. And that is why I personally think Professor Lasson's piece to be of great academic value insofar as it alerts us to the more unsavoury aspects of legal scholarship and makes (or ought to make) all academics take stock of their respective positions. It is unfortunate that the points were not argued more thoroughly and with the requisite moderation. But, then again, Professor Lasson may beg to differ.

* Senior Lecturer, Faculty of Law, National University of Singapore. (C) 1991. (1990-91) 2 Legal Educ Review 277.

1 (1990) 103 Harv L Rev 926.

2 CA Wright, “Goodbye to Fred Rodell” (1980) 89 Yale LJ 1455; F Rodell, “Goodbye to Law Reviews — Revisited” — (1962) 48 Va L Rev 279. 